\title{
BACE1 inhibitor drugs in clinical trials for Alzheimer's disease
}

\author{
Robert Vassar
}

\begin{abstract}
$\beta$-site amyloid precursor protein cleaving enzyme 1 (BACE1) is the $\beta$-secretase enzyme required for the production of the neurotoxic $\beta$-amyloid (A $\beta$ ) peptide that is widely considered to have a crucial early role in the etiology of Alzheimer's disease (AD). As a result, BACE1 has emerged as a prime drug target for reducing the levels of $A \beta$ in the AD brain, and the development of BACE1 inhibitors as therapeutic agents is being vigorously pursued. It has proven difficult for the pharmaceutical industry to design BACE1 inhibitor drugs that pass the blood-brain barrier, however this challenge has recently been met and BACE1 inhibitors are now in human clinical trials to test for safety and efficacy in AD patients and individuals with pre-symptomatic AD. Initial results suggest that some of these BACE1 inhibitor drugs are well tolerated, although others have dropped out because of toxicity and it is still too early to know whether any will be effective for the prevention or treatment of AD. Additionally, based on newly identified BACE1 substrates and phenotypes of mice that lack BACE1, concerns have emerged about potential mechanism-based side effects of BACE1 inhibitor drugs with chronic administration. It is hoped that a therapeutic window can be achieved that balances safety and efficacy. This review summarizes the current state of progress in the development of BACE1 inhibitor drugs and the evaluation of their therapeutic potential for AD.
\end{abstract}

\section{Introduction}

\section{The role of $\beta$-amyloid in Alzheimer's disease}

The extracellular accumulation of amyloid plaques composed of the $\beta$-amyloid $(A \beta)$ peptide represents one of the two defining lesions in Alzheimer's disease (AD) brain, the other being intracellular aggregation of hyperphosphorylated tau into neurofibrillary tangles. Recent results indicate that amyloid deposition begins $\sim 10-20$ years before the onset of dementia, suggesting that cerebral accumulation of $A \beta$ has as a critical early role in $A D$ pathogenesis [1-3]. If so, then inhibition of $A \beta$ accumulation in the brain may benefit $\mathrm{AD}$, if given early enough during the course of the disease.

Neurons are the major producers of $A \beta$ in the brain, although glia, in particular astrocytes, may also contribute to $A \beta$ generation, particularly during physiological stress that causes glial activation as happens in AD. The formation of $A \beta$ is a sequential proteolytic process beginning with the cleavage of amyloid precursor protein (APP) by the $\beta$ secretase enzyme, which generates the amino $(\mathrm{N})$ terminus

Correspondence: r-vassar@northwestern.edu

Department of Cell and Molecular Biology, Northwestern University, The Feinberg School of Medicine, 303 E. Chicago Avenue, Chicago, IL 60611, USA of $A \beta$ and yields the membrane bound $C$-terminal fragment C99 (Figure 1A) [4]. Next, $\gamma$-secretase cuts C99 to release $A \beta$, which is secreted from the cell [5-7]. Interestingly, the $\gamma$-secretase cut is imprecise and creates $A \beta$ isoforms of different lengths at the carboxy $(C)$ terminus, of which the longer isoforms are highly associated with $\mathrm{AD}$. Processing of APP by both $\beta$ - and $\gamma$-secretases is necessary for the generation of $A \beta$, suggesting that inhibition or modulation of either or both of these proteases in the brain should decrease $\mathrm{A} \beta$ levels and be beneficial for AD.

Human genetics studies have greatly informed us about $\mathrm{AD}$ pathogenesis and strongly suggest that cerebral $A \beta$ accumulation has an essential role in the etiology of $\mathrm{AD}$ [2]. Thus far, over 200 autosomal dominant mis-sense mutations have been identified in the genes for APP and presenilin (the $\gamma$-secretase catalytic subunit) that are associated with familial $\mathrm{AD}$ (FAD). These FAD mutations are highly penetrant and without exception increase either the generation of all $A \beta$ isoforms (total $A \beta$ ) or the relative proportion of the 42-amino acid isoform (A $\beta 42)$ that is more neurotoxic. Notably, FAD mutations in APP are found very near to the $\beta$ - and $\gamma$-secretase cleavage sites, and these mutations serve to increase APP processing and raise levels of total $A \beta$ or $A \beta 42$ specifically. The so-called 

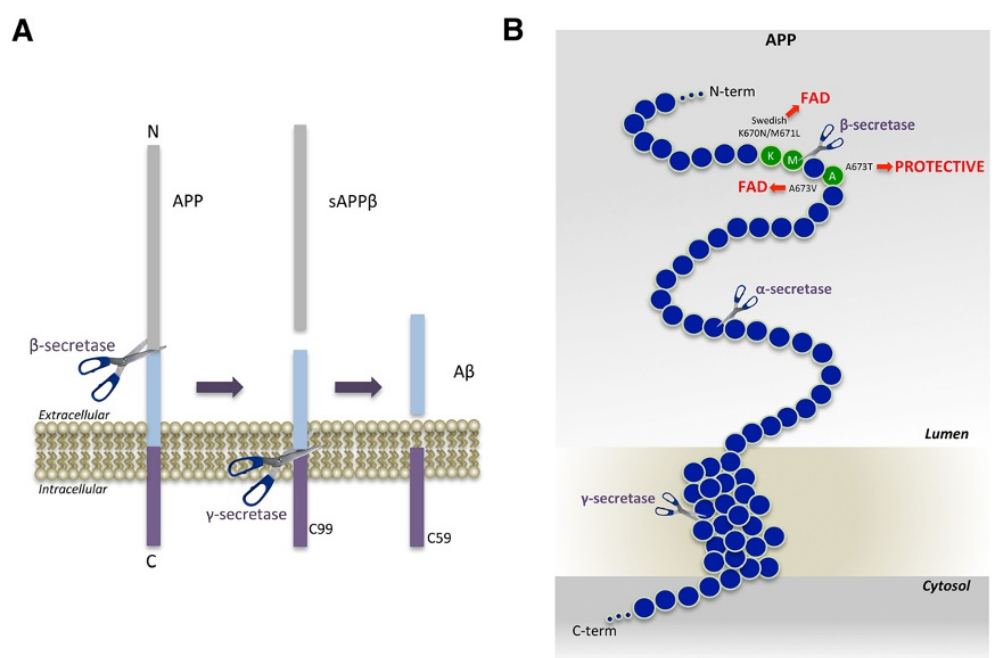

Figure 1 APP processing and $\mathbf{A} \boldsymbol{\beta}$ generation and mutations that affect $\beta$-secretase cleavage. $A$. APP is a Type-l membrane protein that is sequentially cleaved by two aspartic proteases to generate A $\beta$. First, the $\beta$-secretase enzyme cuts APP (1) to create the N-terminus of A 3 . Two APP fragments are produced: membrane-bound C99 and secreted SAPP $\beta$ ectodomain. Second, C99 is cleaved by the $\gamma$-secretase enzyme (2) to generate the $C$-terminus of $A \beta$. $A \beta$ is then released into the lumen of the endosome and secreted into the extracellular medium. An intracellular domain, C59, is also produced. B. The amino acids in and around the A $\beta$ domain of APP are represented as blue circles. Amino acids that affect $\beta$-secretase processing of APP in humans are green circles, within which the wild-type residue is identified by the single-letter amino acid code. The K670N/M671L (Swedish) and A673V mutations cause FAD by increasing $\beta$-secretase cleavage and AB production, while the A673T mutation protects against AD by doing the opposite. All three mutations occur at or within one amino acid of the $\beta$-secretase cleavage site. Scissors indicate cleavage sites of the various secretases.

Swedish mutation (K670N; M671L) [8] and A673V [9] mutations in APP are particularly compelling, because they are positioned precisely at and only 2 amino acids Cterminal to the $\beta$-secretase cleavage site, respectively. These mutations make the cleavage of APP by the $\beta$-secretase enzyme more efficient, so greater amounts of C99 and total $\mathrm{A} \beta$ are generated (Figure 1B). In contrast, an APP mutation, A673T, has been recently identified that confers protection against $\mathrm{AD}$ and cognitive decline in the elderly [10]. This mutation, which occurs at the same position as the A673V mutation that causes FAD, is less efficiently cleaved by $\beta$-secretase so that $A \beta$ generation is decreased by $\sim 40 \%$ [10-12]. Interestingly, most carriers have one copy of the A673T mutation and likely have a reduction in $\mathrm{A} \beta$ production of only $\sim 20 \%$, yet they are still protected against AD. This implies proof-of-principle of the strategy that modest reduction of brain $A \beta$ levels may prevent $A D$, if started early enough. Additionally, the Swedish, A673V, and A673T mutations together strongly suggest that inhibition of $\beta$-secretase cleavage of APP should be beneficial for AD.

\section{Review}

\section{The identification of $\beta$-secretase as $\beta$-site APP cleaving} enzyme (BACE)

Following the discoveries of $A \beta$ and the first APP mutations that cause FAD, it soon became clear that the $\beta$ - and $\gamma$ secretase enzymes were prime therapeutic targets for the development of small molecule inhibitor drugs for the treatment of $\mathrm{AD}$. Thus, their molecular identities were vigorously pursued. The properties of $A \beta$ generation and secretase activities in cells and tissues led to the development of cell-free and cell-based assays that could be exploited for the identification of the secretases. Subsequently, five groups independently reported the molecular cloning of the $\beta$-secretase enzyme, which they variously named $\beta$-site APP cleaving enzyme (BACE), Asp2, and memapsin 2 [13-17] ("BACE" has emerged as the most common moniker in the literature). Importantly, all of the groups agreed on the same polypeptide sequence even though they used different experimental approaches to identify the $\beta$-secretase, lending strong support for the conclusion that the authentic $\beta$-secretase had been cloned.

BACE has all the molecular and cellular characteristics that had been previously predicted for the $\beta$-secretase in vitro and in vivo [4]. It is a Type I transmembrane aspartic protease of 501 amino acids in length that is closely related to the pepsin family of aspartic proteases (Figure 2). The catalytic domain of BACE harbors two aspartic protease signature motifs of the sequence DTGS and DSGT that come together to form the active site of the enzyme. As required for $\beta$-secretase, the BACE active site is topologically oriented on the same side of the membrane as the $\beta$-secretase cleavage site in APP. Additionally, the activity of BACE has an acidic $\mathrm{pH}$ optimum and the catalytic domain resides within the lumen of acidic intracellular compartments, including endosomes and trans-golgi network 


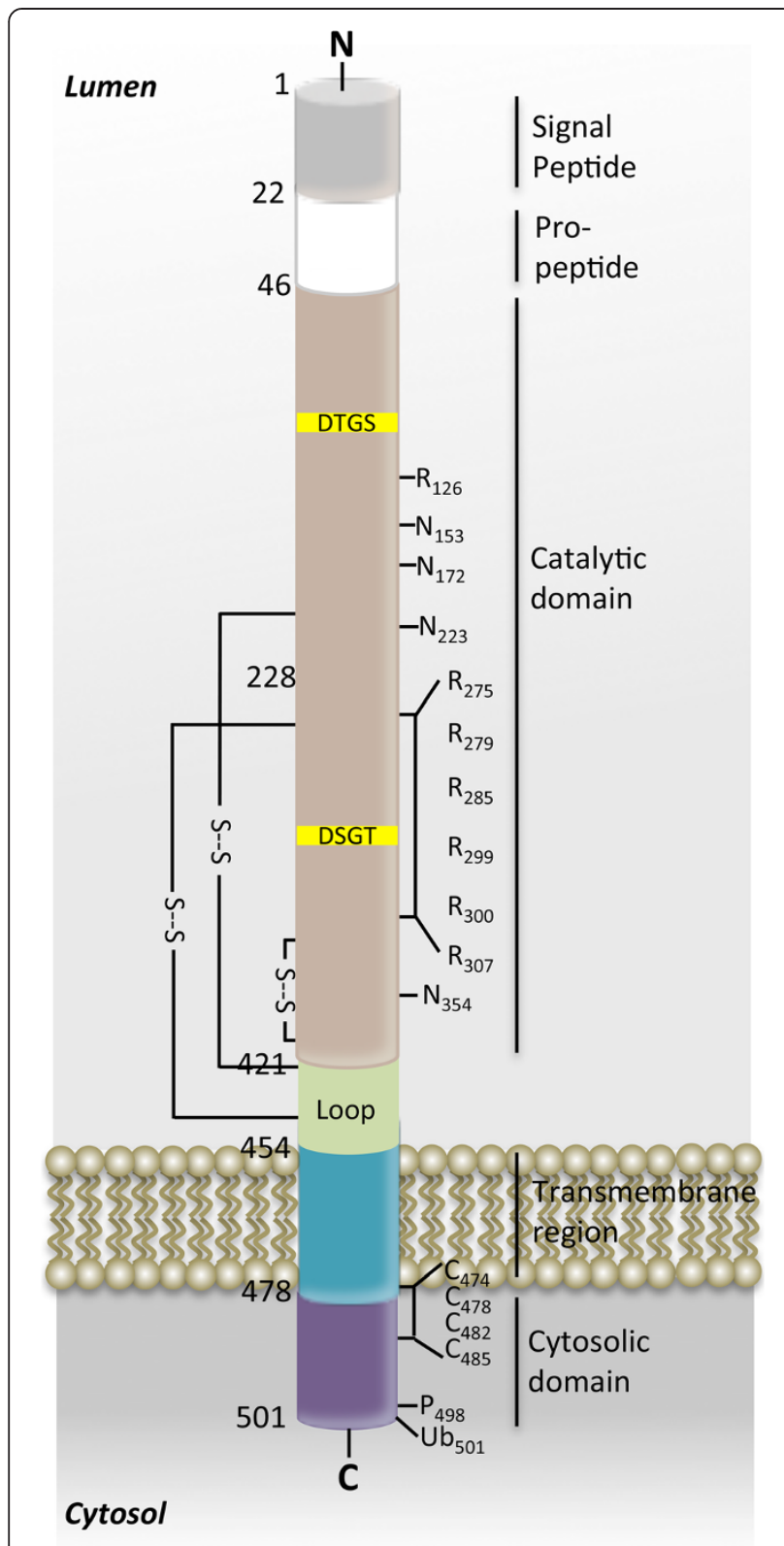

Figure 2 Primary structure of BACE1. BACE1 is a 501 amino acid Type-l transmembrane aspartic protease. The various subdomains of BACE1 are indicated by the lines to the right of the structure. Numbers refer to amino acid positions. The two signature aspartic protease active site motifs at positions 93 and 289 are shaded yellow. S-S denote positions of disulfide bridges within the catalytic domain; Ns represents positions of N-linked glycosylation sites; Rs indicates positions of acetylated arginine residues; Cs mark positions of Spalmitoylated cysteine residues; $\mathrm{P}$ indicates phosphorylation of serine 498; Ub denotes ubiquitination of lysine 501.

(TGN). Moreover, BACE levels are highest in neurons of the CNS, BACE has the correct sequence specificity, and BACE overexpressed in cells cleaves APP and increases $\mathrm{A} \beta$ production.
Soon after the discovery of BACE, a homologue, BACE2, was identified that has $\sim 64 \%$ amino acid similarity to BACE (henceforth referred to as BACE1) [18]. The extensive degree of homology between the two enzymes suggested that BACE2 might also function as a $\beta$-secretase. However, this possibility seemed unlikely because BACE2 is not expressed to a high level in neurons, in contrast to BACE1 $[19,20]$. Moreover, BACE2 predominantly cleaves APP within the $A \beta$ domain, so that the generation of $A \beta$ is precluded [21-25]. These data, together with the finding that BACE1 null mice are devoid of $A \beta$ (see below), suggest BACE2 is not likely to be a $\beta$-secretase in the CNS.

\section{Physiological functions of BACE1 \\ BACE1-/- mice}

To justify BACE1 inhibitor drug development efforts, it was necessary to provide in vivo validation that BACE1 is the primary $\beta$-secretase enzyme in the brain. To do so, gene targeting in embryonic stem cells was used to produce BACE1 knockout (-/-) mice [26-29]. Initial reports showed that BACE1-/- mice were viable and fertile and did not have detectable abnormalities. Their normal morphology and behavior, tissue histology, and blood cell and clinical chemistry characteristics suggested that BACE1 inhibition as a therapeutic approach for AD might lack mechanismbased toxicities. Additionally, APP overexpressing transgenic mice that also lack the BACE1 gene are devoid of cerebral $A \beta$, amyloid deposition, and $A \beta$-associated memory impairments [20,30-33]. Importantly, these data validate BACE1 as the major $\beta$-secretase in the CNS and indicate that BACE2 does not compensate for BACE1 loss of function, at least for the production of $A \beta$. Furthermore, they strongly suggested that BACE1 inhibition should be a safe and effective therapeutic strategy for AD.

Although initial studies of BACE1-/- mice indicated that BACE1 was not required for viability in vivo, further investigations were necessary to elucidate the physiological functions of BACE1 and fully understand the potential for mechanism-based toxicities of therapeutic BACE1 inhibition. For example, BACE1 protein is highly concentrated in presynaptic terminals of CNS neurons [34,35], suggesting that BACE1 has a role in synaptic function. Moreover, in agreement with high BACE1 expression and presynaptic localization in neurons, deeper analyses of BACE1-/- mice have uncovered numerous subtle neuronal phenotypes, such as axon targeting errors [36-38], reduced myelination [39-41], memory impairments [20,30,32,42,43], reduced muscle spindles [44], neurochemical abnormalities [45], alterations in neurogenesis and astrogenesis [46], increased age-related neurodegeneration [47], reduced spine density [48], retinal pathology [49], endophenotypes of schizophrenia [48], and seizures $[42,47,50]$ (Table 1). Future investigations may reveal even more BACE1 null phenotypes. Any of these BACE1 null phenotypes in theory could represent 
Table 1 BACE1 knockout mouse phenotypes

\begin{tabular}{|c|c|c|}
\hline Phenotype & $\begin{array}{l}\text { Putative } \\
\text { Substrate }\end{array}$ & References \\
\hline $\begin{array}{l}\text { Astrogenesis increase; neurogenesis } \\
\text { decrease }\end{array}$ & Jag1 & [46] \\
\hline Axon guidance defects & CHL1 & {$[36-38]$} \\
\hline Hyperactivity & NRG1 & {$[29,48]$} \\
\hline Hypomyelination & NRG1 & [39-41] \\
\hline Memory deficits & Unknown & {$[17,30,32,42,43]$} \\
\hline Insulin sensitivity enhanced & Unknown & {$[29,51,52]$} \\
\hline Muscle spindle reduction & NRG1 & [44] \\
\hline Neurochemical deficits & Unknown & [45] \\
\hline Neurodegeneration with age & Unknown & [47] \\
\hline Postnatal lethality, growth retardation & Unknown & [29] \\
\hline Retinal abnormalities & VEGFR1 & [49] \\
\hline Schizophrenia endophenotypes & NRG1 & [48] \\
\hline Seizures & $\mathrm{Na}_{\mathrm{v}} \mathrm{\beta}_{2}$ & {$[42,47,50,53]$} \\
\hline Spine density reduction & NRG1 & [48] \\
\hline \multicolumn{3}{|l|}{ BACE2 knockout mouse phenotypes } \\
\hline Phenotype & $\begin{array}{l}\text { Putative } \\
\text { Substrate }\end{array}$ & References \\
\hline Normal & - & [29] \\
\hline Pancreatic $\beta$ cell increase & Tmem27 & [54] \\
\hline Pigmentation abnormalities & PMEL & {$[55]$} \\
\hline \multicolumn{3}{|c|}{ BACE1/2 double knockout mouse phenotypes } \\
\hline Phenotype & & References \\
\hline $\begin{array}{l}\text { Similar to BACE1 knockout, except pos } \\
\text { is enhanced }\end{array}$ & natal lethality & [29] \\
\hline
\end{tabular}

mechanism-based side effects of BACE1 inhibitor drugs in humans, thus raising a note of caution that therapeutic inhibition of BACE1 might not be completely free of toxicity.

\section{Substrates of BACE1}

The varied phenotypes of the BACE1-/- mice are likely the result of abrogated $\beta$-secretase processing of different substrates of BACE1 in addition to APP. Recent proteomic analyses in cultured primary neurons have identified numerous putative BACE1 substrates that have roles in neuronal functions [56,57] (Figure 3). The majority of substrates of BACE1 are, like APP, Type I membrane proteins, while a few, like neuregulin 1 (NRG1), have more complex membrane topologies. Cleavage of most substrates by BACE1 releases an ectodomain fragment that diffuses from the cell in the extracellular milieu. There, it may bind to another molecule on the same (autocrine) or a different (paracrine) cell to affect signal transduction or cell-cell interactions. Perhaps the best studied example is that of BACE1 processing of Type III NRG1, which releases an epidermal growth factor (EGF)-like domain that binds to the ErbB receptor on the Schwann cell for the simulation of myelination
$[39,40,58,59]$. Because of the lack of $\beta$-secretase processing, BACE1-/- mice have decreased shedding of the NRG1 EGF domain, which reduces instructive signals to myelinating cells and leads to hypomyelination.

Another example of $\beta$-secretase processing of a neuronal substrate involves the cleavage of the neural cell adhesion molecule close homolog of L1 (CHL1) by BACE1. Like APP, CHL1 is a Type I membrane protein, and it has a well-known function in axonal outgrowth and neuronal survival $[60,61]$. Cleavage of CHL1 by BACE1 liberates a soluble ectodomain fragment that may bind to neuropilin-1 and semaphorin $3 \mathrm{~A}$, two molecules that are involved in axonal guidance. Thus, the lack of $\beta$-secretase processing of CHL1 might account for the presence of mis-targeted axons that have been reported in the olfactory bulb and hippocampus of BACE1 null mice [38,56,57].

Although decreased $\beta$-secretase processing of many BACE1 substrates impairs their function, abrogated cleavage of other substrates may potentiate their role in a physiological process. For example, Jagged 1 (Jag1) is a Type I membrane protein that is a ligand for the Notch receptor, which regulates the differentiation of many cell types in the body. Interestingly, Jag1 is also a BACE1 substrate, and reduced BACE1 cleavage of Jag1 in BACE1-/mice increases the levels of Jag1 on the cell surface, which causes greater than normal stimulation of Notch activity in the neighboring cell. Consequently, during early development Jag1-Notch signaling is increased [62] in radial glial neural stem cells, which promotes astrogenesis over neurogenesis [46]. As additional BACE1 substrates and functions are discovered, the underlying molecular mechanisms of BACE1 null phenotypes and their implications for mechanism-based toxicities of therapeutic BACE1 inhibition will come into clearer focus.

In addition to cleavage by BACE1, a number of BACE1 substrates undergo ectodomain shedding by proteases in the A Disintegrin and Metalloproteinase Domain (ADAM) family. The extent to which a given substrate is processed by BACE1 verses an ADAM family member varies depending on the substrate (Figure 3). Some substrates are almost exclusively cut by BACE1 (e.g., SEZ6, APLP1), while other substrates are primarily cleaved by the ADAMs (e.g., APP, neuroligin-1) [56,57]. One would predict from these results that potential mechanism-based side effects that arise from therapeutic BACE1 inhibition might derive from deficient processing of substrates that predominantly undergo ectodomain shedding by BACE1 rather than the ADAMs. Conversely, potential toxicities of BACE1 inhibition may be less associated with substrates that are primarily cleaved by ADAM proteases over BACE1.

\section{BACE2-/- mice}

The significant amino acid similarity shared by BACE1 and BACE2 suggests that it may be challenging to develop 


\section{$\begin{array}{lr}\text { BACE1 } & \text { ADAM } \\ \text { cleavage } & \text { cleavage }\end{array}$ \\ HIGH Seizure protein 6-like 1 \\ Seizure protein 6 \\ Amyloid precursor-like protein 1 \\ VWFA and cache domain-containing protein 1 \\ Golgi apparatus protein 1 \\ L1 \\ Leucine-rich repeat neuronal protein 1 \\ Plexin domain-containing protein 2 \\ Neurotrimin \\ Cell adhesion molecule with homology to L1CAM \\ Peptidyl-glycine $\alpha$-amidating monooxygenase \\ Alpha-1,4- $\mathrm{N}$-acetylhexosaminyltransferase EXTL2 \\ Protocadherin $\gamma \mathrm{A} 11$ \\ Amyloid precursor-like protein 2 \\ ST3GAL-I sialytransferase \\ Latrophilin-1 \\ Neuroligin-4 \\ Semaphorin-6D \\ Lysosomal membrane glycoprotein 1 \\ Neurexin $\mathrm{l}-\alpha$ \\ Protocadherin-20 \\ Latrophilin-3 \\ Latrophilin-2 \\ Sodium/potassium-dependent ATPase subunit $\beta-1$ \\ Delta and Notch-like epidermal growth factor-related receptor \\ Interferon $\alpha / \beta$ receptor 2 \\ Neuroligin-2 \\ Seizure 6-like protein 2 \\ Leucine-rich repeat fibronectin type-III domain-containing \\ protein 2 \\ Cx3C membrane-anchored chemokine \\ Contactin-2 \\ Amyloid precursor protein \\ Neuroligin-1 \\ Transmembrane protein 132A

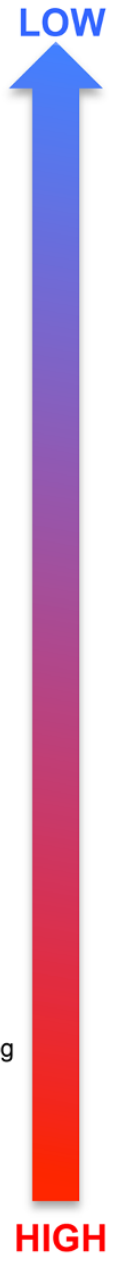

Figure 3 Neuronal substrates of BACE1. BACE1 substrates identified in primary cultured neurons are listed from those that are predominantly cleaved by BACE1 (BACE1 cleavage HIGH; top) to those that are processed by BACE1 at a low level (LOW; bottom). These substrates also are cleaved by other proteases in the ADAM family, but the ADAM cleavage preference is opposite to that of BACE1. (Adapted from Table I, Ref. [56]).

BACE1 inhibitors that do not cross-inhibit BACE2. Therefore, the possibility exists that BACE1 inhibitor drugs might also cause BACE2 mechanism-based side effects in addition to those of BACE1. To investigate this question, BACE2-/mice were produced by gene-targeting. Like BACE1 null mice, the BACE2-/- mice were initially shown to be viable and fertile with no reported phenotype [29]. Moreover, other than enhanced early postnatal lethality, BACE1-/-; BACE2-/- double knockout mice did not have a more severe phenotype than the BACE1-/- single knockouts [29]. These data suggest that cross-inhibition of BACE2 with BACE1 inhibitors might not be associated with enhanced toxicity in the adult after postnatal development is completed.

Although BACE2-/- mice initially were reported to be normal, further investigations have revealed BACE2 loss-of- function phenotypes. Pancreatic $\beta$-cells express significant levels of BACE2. Interestingly, BACE2-/- mice have increased $\beta$-cell mass and insulin levels, and the mice exhibit enhanced glucose regulation [54]. These phenotypes appear to be the result of abrogated BACE2 cleavage of pro-proliferative Type I transmembrane protein Tmem27, a protein involved in the regulation of $\beta$-cell mass. Given these results, inhibition of BACE2 may be beneficial for the treatment of Type 2 diabetes, although further research into this hypothesis is necessary.

In addition to the pancreatic phenotype, BACE2-/- mice on a C57BL/6 genetic background exhibit hypopigmentation that results in a silvery coat compared to the dark coat of wild-type C57BL/6 mice. This phenotype is caused by lack of BACE2 processing of the melanocyte protein PMEL that is expressed in pigment cells of the skin and eye. BACE2 
cleavage releases a fragment of PMEL into melanosomes that forms a matrix of amyloid fibrils upon which melanin is deposited [55]. Consequently, abrogated processing of PMEL in BACE2-/- mice leads to abnormal melanosome formation and hypopigmentation. These results suggest the possibility that cross-inhibition of BACE2 by BACE1 inhibitors might cause reduced pigmentation in humans.

\section{Small molecule BACE1 inhibitor drugs and clinical trials for $A D$}

The extensive validation of BACE1 as the primary $\beta$ secretase enzyme in the CNS has spurred vigorous efforts to develop small molecule inhibitors of BACE1 in both academia and industry. The first generation of BACE1 inhibitors consisted of non-cleavable peptide-based transition state analogs designed after the amino-acid sequence in APP at which $\beta$-secretase cleaves $[15,63]$. Typically, these large peptidomimetic molecules are very potent BACE1 inhibitors in vitro, mainly because the large open active site of BACE1 has evolved to bind polypeptide substrates with high affinity. Unfortunately, the peptide-based BACE1 inhibitors did not possess favorable in vivo pharmacological properties, such as oral bioavailability, long serum half-life, or blood-brain barrier (BBB) penetration. As a consequence, investigators have turned toward designing true small molecule BACE1 inhibitor drugs. However, the development of non-peptidic BACE1 inhibitors large enough to bind with sufficient affinity to the enzymatic active site, yet small enough to exhibit satisfactory pharmacokinetics and suitable brain penetration has proven to be very challenging. Moreover, BACE1 inhibitors should have sufficient lipophilicity to cross both plasma and endosomal membranes for gaining access to the vesicle lumen where the BACE1 active site is located.

A crucial advance in small molecule BACE1 inhibitor development came with the first X-ray co-crystal structure of BACE1 with a peptidic BACE1 inhibitor [64]. The BACE1 $\mathrm{X}$-ray structure revealed important inhibitor-enzyme interactions that were exploited in rational drug design efforts. Shortly thereafter, new classes of small molecule BACE1 inhibitors were developed that exhibited improved pharmacological characteristics, including small molecular weight, plasma membrane permeability, and better pharmacokinetics $[65,66]$. However, most second-generation BACE1 inhibitors were substrates of P-glycoprotein, the ATPdependent drug efflux pump for xenobiotics in the BBB [67], and therefore could not reach high concentrations in the brain.

More recently, potent third-generation small molecule BACE1 inhibitors have been developed that achieve satisfactory brain penetration and robust cerebral $A \beta$ reduction in preclinical animal models. Innovative diverse and complex drug development approaches have been employed to design current BACE1 inhibitors, which are described in detail in recent reviews $[65,66]$. Several of these orally bioavailable BACE1 inhibitor drugs have entered into human clinical trials (Table 2). Most are in the early clinical phases and scant information on their progress has been published, although preliminary trial results for three BACE1 inhibitor drugs have been reported at recent conferences and are summarized below.

\section{LY2886721}

The pharmaceutical company Eli Lilly was among the first to develop and test orally bioavailable non-peptidic BACE1 inhibitors in humans. The small molecule BACE1 inhibitor LY2811376 showed satisfactory pharmacokinetic and pharmacodynamic characteristics in preclinical animal models that translated to a Phase 1 clinical trial in humans [68]. However, chronic toxicology studies in rat showing nonclinical non-target associated pathology in retina and brain precluded the clinical development of this molecule. Although it was discontinued, LY2811376 demonstrated the feasibility of developing a potent brain-penetrant orally bioavailable small molecule BACE1 inhibitor and represented the first reported translation of reduced CSF biomarkers of BACE1 cleavage from preclinical animal models to humans.

Lilly advanced a next-generation compound, LY2886721, into Phase 1 and 2 clinical trials to determine its safety and tolerability, pharmacokinetics, and pharmacodynamics. Similar to LY2811376, LY2886721 was a potent orally bioavailable small molecule BACE1 inhibitor that robustly decreased levels of $A \beta$ in the brains of preclinical animal models. However, unlike LY2811376, treatment with LY2886721 did not appear to be toxic to the retina or brain. Forty-seven healthy volunteers were given daily oral doses of either LY2886721 or placebo for 14 days in Phase 1 [69]. Either a multiple ascending dose $(5,15$, and $35 \mathrm{mg})$ or a single dose $(70 \mathrm{mg})$ followed by a multiple ascending

Table 2 Small molecule BACE1 inhibitors in clinical trials

\begin{tabular}{lll}
\hline Company & Drug & Phase \\
\hline AstraZeneca/Lilly & AZD3293 & Phase 2/3 \\
CoMentis & CTS-21166 & Phase 1 \\
Eisai/Biogen Idec & E2609 & Phase 2 \\
High Point & HPP854 & Phase 1 \\
Janssen/Shionogi & - - - - & Phase 1 \\
Lilly & LY2886721 & Phase 2* \\
Merck & MK-8931 & Phase 2/3 \\
Novartis & - - - - & Phase 1 \\
Pfizer & PF-05297909 & Phase 1 \\
Roche & RG7129 & Phase 1** \\
Takeda & TAK-070 & Phase 1 \\
Vitae/Boehringer Ingelheim & VTP-37948 & Phase 1 \\
\hline
\end{tabular}

*Terminated due to abnormal liver biochemistry.

**Removed from pipeline. 
dose was performed in two Phase 1 study designs (NCT01227252, NCT01534273). Over the course of the 14-day study, LY2886721 was reported to be safe and well tolerated. Plasma half-life of LY2886721 was 12 hours, compatible with once per day dosing. Dose-dependent decreases of both plasma and CSF A $\beta 40$ levels resulted from LY2886721 administration. A $\beta 40$ levels in the CSF were decreased up to $74 \%$ with the highest dose of LY2886721. Levels of A $\beta 42$ and SAPP $\beta$ in the CSF were both reduced to a similar extent as CSF A $\beta 40$ by LY2886721. Interestingly, levels of sAPP $\alpha$, the $\alpha$-secretase cleavage product, were increased in CSF [70], an observation that is consistent with BACE1 inhibition, since $\beta$ - and $\alpha$-secretase compete for processing of APP. A Phase 1 study of LY2886721 in patients with $\mathrm{AD}$ was also conducted (NCT01807026).

The positive Phase 1 trials led to a six-month Phase 2 trial of 35 or $70 \mathrm{mg}$ of LY2886721 dosed orally once per day in 130 patients with prodromal $\mathrm{AD}$, also known as amnestic mild cognitive impairment (MCI), or mild AD (NCT01561430) [71]. Recently, Lilly voluntarily terminated the Phase 2 trial because a small number of subjects that were given LY2886721 developed abnormal liver biochemistries. The company reported that the LY2886721-related liver abnormalities did not appear to be associated with the BACE1 mechanism of action, a conclusion supported by a normal liver phenotype of BACE1-/- mice. It is not uncommon that some small molecules in clinical development are discontinued because of abnormal liver function as a non-target related side effect. Thus, the termination of LY2886721 does not necessarily suggest that BACE1 is not a viable drug target.

\section{MK-8931}

MK-8931, a small molecule BACE1 inhibitor developed by the pharmaceutical company Merck was tested in 88 healthy volunteers (18-45 years old) as a two-part randomized, double-blind, placebo-controlled Phase 1 clinical trial [72]. Single and multiple (daily for 14 days) oral doses of MK-8931 were analyzed for safety, tolerability, pharmacokinetics, and pharmacodynamics. In healthy volunteers, MK-8931 was well tolerated and no serious adverse events were reported. Determining whether MK-8931 was able to enter the brain and engage its target, the $\beta$-secretase enzyme, were primary goals of the study. To do so, biomarkers of BACE1 activity were measured in the CSF, including $A \beta 40, A \beta 42$, and $S A P P \beta$, the latter being the BACE1-cleaved ectodomain of APP. MK-8931 markedly reduced levels of $A \beta$ in the CSF in a sustained and dosedependent manner. A single oral dose of 100 or $550 \mathrm{mg}$ of MK-8931 decreased CSF A 340 levels by $75 \%$ or $92 \%$, respectively, at 36 hours after dosing. Levels of $A \beta 42$ and sAPP $\beta$ in the CSF were also reduced to similar extents. Multiple oral dosing of MK-8931 lowered A $\beta$ levels in the CSF by over $90 \%$. MK-8931 has a plasma half-life of $\sim 20$ hours, suggesting that a single daily oral dose may maintain stable drug levels in vivo.

A randomized, double-blind, placebo-controlled Phase $1 \mathrm{~b}$ trial of MK-8931 in 32 mild to moderate AD patients (mean age and Mini-Mental State Examination (MMSE), 73 yrs. and 22, respectively) was also conducted for safety, tolerability, pharmacokinetics, and pharmacodynamics (NCT01496170) [73]. One of three doses (12, 40, or $60 \mathrm{mg}$ ) of MK-8931 or placebo was given once each day orally for 7 days and levels of $A \beta 40, A \beta 42$, and sAPP $\beta$ in the CSF were measured. Similar to the healthy volunteers, MK-8931 strongly decreased levels of A $\beta$ in the CSF in a sustained and dose-dependent fashion. Daily dosing of 12 , 40 , or $60 \mathrm{mg}$ reduced CSF A $\beta 40$ by 57,79 , or $84 \%$, respectively, and resulted in similar reductions for CSF A $\beta 42$ and sAPP $\beta$. MK-8931 did not appear to cause serious adverse events in the AD patients during the course of the study. Importantly, the MK-8931 Phase 1b results suggest that the pharmacokinetic and pharmacodynamic properties of BACE1 inhibitor drugs are not significantly altered by the presence of high amyloid loads in the brains of $\mathrm{AD}$ patients.

Encouraged by the positive results of the MK-8931 Phase 1 and $1 \mathrm{~b}$ studies, a Phase 2/3 combined clinical trial (the EPOCH study, NCT01739348) was started in late 2012. $\mathrm{EPOCH}$ is a 78-week, randomized, placebo-controlled, parallel-group, double-blind clinical trial to evaluate the safety and efficacy of 12 or $40 \mathrm{mg} /$ day oral dosing of MK8931 versus placebo in mild to moderate AD patients. In Phase 2 the trial will evaluate $200 \mathrm{AD}$ patients and will enroll up to 1,700 patients for Phase 3. Primary efficacy outcomes are the changes from baseline in the Alzheimer's Disease Assessment Scale Cognitive Subscale (ADAS-Cog) and the Alzheimer's Disease Cooperative Study-Activities of Daily Living (ADCS-ADL) scores.

A recent interim safety analysis in $200 \mathrm{AD}$ patients treated with MK-8931 for at least 3 months suggested that the drug was well tolerated and that the EPOCH study proceed without changes to the protocol. Enrolment in the trial has continued with up to 1960 patients expected for Phase 3. An additional clinical trial (the APECS study, NCT01953601) has also commenced, consisting of a 104 week randomized, placebo-controlled, parallel-group, double-blind Phase 3 study to evaluate the safety and efficacy of $12 \mathrm{mg}$ or $40 \mathrm{mg}$ per day oral dosing of MK-8931 versus placebo in 1500 patients with MCI. The primary efficacy outcome in APECS is the change from baseline in the Clinical Dementia Rating Scale-Sum of Boxes (CDRSB) score. Secondary outcome substudies are included in both $\mathrm{EPOCH}$ and APECS to measure $\mathrm{AD}$ biomarkers, consisting of cortical amyloid load, CSF A $\beta$ and tau, and hippocampal volume. The Phase 3 efficacy studies for EPOCH and APECS are expected to conclude in 2017 and 2018, respectively. 


\section{AZD3293}

The AstraZenica BACE1 inhibitor, AZD3293, was recently tested for safety, tolerability, pharmacokinetics, and effects on plasma and CSF A $\beta$ levels in healthy young (18-55 yr) and elderly (55-80 yr) subjects [74]. Phase 1 randomized, double-blind, placebo-controlled SAD and MAD studies were conducted. In the SAD study (NCT01739647), 1 to $750 \mathrm{mg}$ doses of AZD3293 were administered to 7 young cohorts, while an elderly cohort received $15 \mathrm{mg}$ (8 subjects/ cohort). In the MAD study (NCT01795339), multiple once-daily doses of AZD3293 ranging from 15 to $70 \mathrm{mg}$ were administered to 5 cohorts (two elderly) for 2 weeks. AZD3293 was well tolerated with no serious adverse events reported up to the highest dose given $(750 \mathrm{mg})$ in the SAD study. The half-life of AZD3293 was 11-20 hours and thus compatible with once daily dosing. Pharmacokinetic parameters of AZD3293 between elderly and young subjects were indistinguishable. In the MAD study, the 15 or $50 \mathrm{mg}$ doses reduced CSF $A \beta 40$ and $A \beta 42$ concentrations by a constant 50 or $75 \%$, respectively. Additionally, AZD3293 administration produced dose-dependent decreases and increases of sAPP $\beta$ and sAPP $\alpha$ concentrations in the CSF, respectively, that had similar timelines as the reductions in CSF A $\beta 40$ and A 442 [75]. The Phase 1 studies of AZD3293 in health subjects (NCT01739647) and AD patients (NCT01795339) have been completed, and combined Phase $2 / 3$ trials in 1,551 $\mathrm{MCI}$ and mild $\mathrm{AD}$ patients are planned $(20 \mathrm{mg}$ or $50 \mathrm{mg}$ doses, 104 week duration, AMARANTH trial (NCT02245737)). Recently, AstraZenica and Lilly entered into a partnership to jointly develop AZD3293 for AD.

\section{E2609}

The drug company Eisai has developed an orally bioavailable small molecule BACE1 inhibitor, E2609, that has shown robust lowering of cerebral $A \beta$ in preclinical and clinical studies. E2609 was first clinically studied in healthy volunteers in randomized, double-blind, placebocontrolled Phase 1 trials [76-78]. A single oral ascending dose (SAD) study (73 subjects) and a 14-day multiple oral ascending dose (MAD) study (50 subjects) tested E2609 in two separate Phase 1 clinical trials (NCT01294540 and NCT01511783, respectively). The SAD study analyzed plasma A $\beta$ levels following E2609 administration ranging from 5 to $800 \mathrm{mg}$ ( 9 cohorts), while the MAD study measured both plasma and CSF A $\beta$ levels in response to E2609 doses ranging from 25 to $400 \mathrm{mg}$ (5 cohorts). The E2609 plasma half-life of 12-16 hours is compatible with once per day dosing. Each of the two Phase 1 studies showed robust dose-dependent decreases of levels of $A \beta$ in the CSF and/or plasma. CSF A $\beta$ levels were reduced up to $85 \%$ at the highest dose of E2609 (400 mg) in the MAD study. Similar decreases in levels of sAPP $\beta$ in the CSF were observed, while CSF levels of sAPP $\alpha$ were increased. E2609 appeared to be safe and well tolerated, as no serious adverse events were reported in either Phase 1 study. Eisai has recently completed a Phase 1 trial of E2609 in subjects with MCI or mild AD (NCT01600859), and a Phase 2 clinical trial of E2609 is planned. Recently, Eisai and Biogen Idec entered into a partnership to jointly develop E2609 for AD.

\section{Alternative therapeutic approaches for BACE1 inhibition}

Although small molecules that directly inhibit BACE1 enzyme activity are leading therapeutic approaches, potential alternative strategies to reduce BACE1 processing of APP are being explored. As noted, BACE1 levels are significantly elevated in $\mathrm{AD}$ brain and might accelerate the production of $\mathrm{A} \beta$. Therefore, approaches to lower and normalize BACE1 levels in the brain might slow AD progression and avoid possible untoward side effects caused by direct BACE1 enzyme inhibition. Consequently, efforts are underway to elucidate the mechanisms of BACE1 elevation in $\mathrm{AD}$ in order to identify drug targets that could block the BACE1 increase when inhibited. BACE1 undergoes complex regulation at the transcriptional, translational, and post-translational levels, all of which appear to have a role in elevating BACE1 levels and activity in AD [79-81]. Much evidence suggests that BACE1 is a stress response protease that is increased by oxidative stress, inflammation, hypoxia, and trauma, among other insults that occur in $\mathrm{AD}$ $[79,82,83]$. Even $A \beta$ itself increases BACE1 levels in neurons $[84,85]$, suggesting a vicious pathogenic cycle whereby $A \beta$ could accelerate its own production through BACE1 elevation. Which, if any, of these complex multi-layered regulatory mechanisms might yield therapeutic strategies for lowering BACE1 levels in AD is unclear, but continuing research in this important area may reveal promising new $\mathrm{AD}$ drug targets in the future.

Another class of alternative therapeutic strategy for BACE1 inhibition involves immunotherapy approaches to reduce BACE1 processing of APP. The first of these strategies employs antibodies directed against the $\beta$-secretase cleavage site of APP that sterically block access of the BACE1 active site to APP $[86,87]$. These anti- $\beta$-site APP antibodies decrease $A \beta$ production cultures cells and when injected i.v. reduce amyloid plaque pathology in the brains of APP transgenic mice [88]. Other immunotherapy approaches include anti-BACE1 antibodies that are not directed against the active site but instead target an exosite on the surface of the BACE1 catalytic domain that can allosterically regulate enzyme activity $[89,90]$. This exosite is located on structurally adjacent regions of the $\mathrm{C}, \mathrm{D}$, and F loops of the enzyme [91]. Exosite antibody binding to BACE1 alters structural features and dynamic characteristics near the substrate binging cleft of the enzyme. Additionally, transport of BACE1 antibodies across the $\mathrm{BBB}$ has been facilitated by engineering one arm of the antibody to recognize transferrin receptor (TfR), which 
shuttles transferrin across the BBB for the delivery of iron into the brain $[92,93]$. These bispecific BACE1-TfR antibodies accumulate in the brain and reduce endogenous $A \beta$ levels in mice to a much greater extent than monospecific BACE1 antibodies. Moreover, TfR bispecific antibodies could be useful for treating other neurologic diseases amenable to immunotherapy. These antibody approaches are currently in preclinical phases.

\section{Unanswered questions that are relevant to BACE1 inhibitor clinical trials}

Fifteen years after the discovery of the $\beta$-secretase enzyme, the challenges of developing brain-penetrant BACE1 inhibitors have been accomplished and human clinical trials are underway. This promising development raises hopes that disease-modifying therapies employing BACE1 inhibition for $A D$ are within reach. However, important questions concerning therapeutic goals and outcomes of these trials remain to be answered:

\section{What degree of BACE1 inhibition will be needed to achieve efficacy?}

The level of BACE1 inhibition required for efficacy in turn should depend on how much $A \beta$ lowering is necessary and at what stage of $\mathrm{AD}$ to treat (questions discussed further below). The recently discovered A673T APP mutation that protects against $\mathrm{AD}[10]$ suggests that reducing cerebral $\mathrm{A} \beta$ production by only a modest amount $(20 \%)$ could be preventative, if started before significant amyloid accumulation. As discussed above, the leading BACE1 inhibitors currently in clinical trial are capable of this relatively small $A \beta$ decrease. How BACE1 inhibition translates to $A \beta$ reduction in the brain is difficult to estimate, although some insight into this question may be gained by considering experiments in BACE1 knockout mice. Heterozygous BACE1+/mice that model $50 \%$ therapeutic inhibition of BACE1 exhibit $\sim 20 \%$ lowering of cerebral A $\beta$ levels in APP transgenic mice [20,33]. Importantly, BACE1+/- mice appear to be normal, so $50 \%$ BACE1 inhibition may circumvent mechanism-based side effects yet provide sufficient $A \beta$ reduction for efficacy.

As suggested by the protective A673T mutation, a therapeutic approach that reduced BACE1 activity and A $\beta$ levels by $\sim 50 \%$ and $\sim 20 \%$, respectively, would probably need to start before major amyloid deposition and be maintained for the remainder of life to prevent or delay the onset of AD. However, inhibiting BACE1 by more than $50 \%$ could be required if significant amyloid plaque load is present in the brain at the beginning of treatment. Still, the possibility exists that no level of BACE1 inhibition, no mater how strong, would be able to slow the progression of $\mathrm{AD}$ once a certain threshold of amyloid burden is reached. At present, these arguments are all speculative, as the levels of BACE1 inhibition and $A \beta$ reduction necessary for efficacy in humans are as yet unknown, although insight into these parameters might be gleaned following analysis of the results from the ongoing clinical trials.

It is important to note that cerebral BACE1 levels in $\mathrm{AD}$ patients are increased by several fold over those in normal individuals [94-97]. Both BACE1 and APP accumulate in swollen dystrophic neurites that surround amyloid plaques $[34,98,99]$, suggesting increased peri-plaque $A \beta$ production that might accelerate amyloid deposition and induce a vicious pathogenic cycle [100]. If so, normalization of BACE1 activity in peri-plaque dystrophic neurites may represent a modest but potentially efficacious therapeutic goal of BACE1 inhibition. However, elevated concentrations of BACE1 around plaques might necessitate the administration of very high BACE1 inhibitor doses in order to significantly reduce peri-plaque $A \beta$ generation, if the amyloid burden is great.

\section{What stage of $A D$ should we administer BACE1 inhibitors?}

Cerebral $A \beta$ accumulation has a crucial early role in $A D$ pathogenesis, as suggested by over 200 FAD mutations [2]. Amyloid deposition appears to begin more than a decade before the manifestation of cognitive deficits and the clinical diagnosis of $\mathrm{AD}$ [101-103]. A $\beta$-lowering BACE1 inhibitors are likely to be most effective as a prevention strategy when administered early in the course of $\mathrm{AD}$, before significant cerebral amyloid accumulation and neurodegeneration. Thus, BACE1 inhibitors are analogous to the cholesterol-lowering statin drugs for the prevention of heart disease: once significant amounts of cholesterol have deposited in coronary arteries and major injury to the heart has occurred, statin administration is unable to reverse the damage and provide much benefit for the patient. AD prevention trials will necessarily involve the enrollment of thousands of subjects, last for years, and incur enormous costs. As a result, AD prevention trials might be most feasible in the context of joint government-industry collaborations, such as those being conducted or planned by the Anti-Amyloid Treatment in Asymptomatic Alzheimer's Disease (A4) trial, Alzheimer's Prevention Initiative (API), and Dominantly Inherited Alzheimer Network Trials Unit (DIAN TU). Some AD prevention trials are enrolling cognitively normal individuals that are genetically at high risk for developing $\mathrm{AD}$ who carry autosomal dominant FAD mutations (DIAN TU trial) or are homozygous for the apolipoprotein E $\varepsilon 4$ allele (API trial). If BACE inhibitors are as well tolerated in chronic dosing for $\mathrm{AD}$ as the statins are for lowering serum cholesterol to prevent heart disease, then treating pre-symptomatic at-risk individuals for $\mathrm{AD}$ prevention is warranted.

Current BACE1 inhibitor trials have enrolled mild and moderate $\mathrm{AD}$ or mild cognitive impairment (MCI), the latter of which progresses to $\mathrm{AD}$ at a rate of $\sim 10-15 \%$ per year [104]. A major advance has been the development of 
amyloid positron emission tomography (PET) imaging and CSF A 342 measurement as biomarkers for the diagnosis of prodromal AD $[105,106]$. Individuals that exhibit significant amyloid load by PET or have reduced CSF A $\beta 42$ concentrations are likely to develop $\mathrm{AD}$, even though they appear cognitively normal at the time of testing. Due to the unavailability of amyloid PET or CSF A $\beta 42$ biomarker testing at the time, past $A \beta$ immunotherapy trials were unable to exclude subjects that did not have cerebral amyloid accumulation, thus leading to increased variability in cognitive outcome results and ultimately contributing to the frank failure of these clinical trials [107]. In contrast, the BACE1 inhibitor clinical trials are enrolling only subjects that are positive by amyloid PET or CSF A $\beta 42$, which should decrease data variability and increase the probability of observing statistically significant differences in cognition between drug and placebo groups. Periodic amyloid PET or CSF A 342 testing will be conducted to monitor target engagement and amyloid accumulation over the courses of the trials. Cognitive performance will also be tested, as this measure is the gold standard for efficacy in past AD clinical trials of approved palliative drugs that treat memory symptoms. However, as noted above, amyloid deposition appears to start years before memory deficits are detected with current tests of cognition. Thus, it might be challenging for BACE1 inhibitors to alter the trajectory of $\mathrm{AD}$ once a large amount of amyloid has accumulated in the brain, at least regarding the reduction of cognitive decline.

It is hoped that the levels of BACE1 inhibition and $A \beta$ reduction necessary for disease modification could be deduced from data collected at the conclusion of the current clinical trials. Pharmacodynamic models developed from this future data might assist in the estimation of the level of BACE1 inhibition required to achieve efficacious $A \beta$ reduction for a given cerebral amyloid load and level of cognitive impairment. These models could also be useful for the design of future primary and secondary $\mathrm{AD}$ prevention trials in pre-symptomatic individuals. At this time, the relationships between BACE1 inhibition, $A \beta$ reduction, amyloid load, and cognitive status are not sufficiently well understood to develop accurate pharmacodynamic models for estimating the levels of BACE1 inhibition needed at a given stage of asymptomatic or symptomatic AD.

\section{Will treatment with BACE1 inhibitors cause mechanism-based side effects?}

Although BACE1-/- mice were initially reported to be normal, recent studies have identified over a dozen BACE1 null phenotypes and substantially more BACE1 substrates (Table 1, Figure 3), suggesting therapeutic BACE1 inhibition might cause mechanism-based toxicities. That said, it is unclear to what extent BACE1 null phenotypes in mice are able to model potential BACE1 inhibitor side effects in humans, for several reasons. First, BACE1 null phenotypes could relate to functions of BACE1 either during development or in adulthood, since BACE1-/- mice lack BACE1 from conception. For example, the major proportion of myelination occurs during development and is completed when adulthood is reached [108], indicating that hypomyelination as a result of abrogated BACE1 processing of NRG1 in BACE1-/- mice is a developmental phenotype. Consequently, BACE1 inhibition in the adult might not have an impact on myelination, unless re-myelination following injury becomes necessary. In contrast, neurogenesis and axon guidance are ongoing processes that occur in specific neuronal subpopulations that regenerate throughout life $[38,46]$, suggesting the possibility that BACE1-/abnormalities in neurogenesis and axon targeting are adult phenotypes and that BACE1 inhibitor treatment might lead to similar defects. Additionally, it is possible that compensation from other proteases during development could mitigate the effects of BACE1 null mutation, in which case BACE1 inhibitor treatment in humans might have more severe side effects than indicated by BACE1-/- mice. Given these arguments, comprehensive analyses of BACE1-/mice should help to parse developmental verses adult BACE1 null phenotypes for the estimation of BACE1 inhibitor side effect risk.

The risk of BACE1 mechanism-based toxicities will depend in large part on the degree of therapeutic BACE1 inhibition. At one extreme, BACE1-/- mice model 100\% BACE1 inhibition, but this level of inhibition will never be achieved by BACE1 inhibitor treatment in practice, thus reducing the chance of side effects. However, AD patients are elderly and often frail, thus increasing the risk of serious adverse events caused by BACE1 inhibition. Moreover, BACE1 inhibitors must be chronically administered, necessitating a high level of safety. Ongoing and future BACE1 inhibitor clinical trials will ultimately answer these questions. It is anticipated that a therapeutic window will be discovered in which an empirically determined range of BACE1 inhibitor doses can balance tolerable mechanismbased side effects with sufficient reduction of cerebral $A \beta$ levels for efficacy.

The statins are useful as a group for modeling the clinical development of BACE1 inhibitors, as indicated by the fact that the statin clinical trials determined a therapeutic dose window of HMG Co-A reductase inhibitor that effectively decreased serum cholesterol levels to prevent heart disease in the presence of tolerable side effects. We are now in the early phases of this clinical development model for BACE1 inhibitors. Regardless of the final outcomes of the current BACE1 inhibitor trials, invaluable knowledge will be gained about the quantitative and temporal relationships between BACE1 inhibition, $A \beta$ reduction, amyloid burden, and cognitive function in humans, which will be used for future clinical development of BACE1 inhibitors for AD. 


\section{Conclusions}

As the $\beta$-secretase enzyme that initiates the production of $\mathrm{A} \beta, \mathrm{BACE} 1$ is a key therapeutic target for $\mathrm{AD}$. The protective A673T APP mutation in humans and genetic deletion of BACE1 in mice both decrease $A \beta$ generation via reduced $\beta$-secretase processing of APP, providing strong proof of concept that BACE1 inhibition should be efficacious for AD. However, BACE1 null mice exhibit multiple complex neurological phenotypes (Table 1), suggesting that BACE1 inhibitor drugs might cause mechanism-based side effects involving hypomyelination, seizure, axon guidance defects, memory deficits, neurogenesis abnormalities, and neurodegeneration, and potentially others, resulting from insufficient BACE1 processing of a growing list of BACE1 substrates in neurons. Which, if any, of these BACE1 null phenotypes model BACE1 inhibitor side effects in humans remains to ne determined.

Despite the challenges of BACE1 inhibitor drug development over the past 15 years since the discovery of BACE1, the recent introduction of several BACE1 inhibitors into clinical trials has refocused attention on this promising therapeutic approach for AD. To date, Merck's MK-8931 has advanced the farthest to Phase 2/3, while the other drugs including those from AstraZeneca, Eisai, and Pfizer, among others, are in Phases 1 and 2. These compounds are potent, achieving up to $\sim 90 \%$ CSF A $\beta$ reduction. Additionally, they are well-tolerated for the most part, although two BACE1 inhibitors have recently been terminated due to toxicity that might not be related to the BACE1 mechanism of action.

The most challenging questions for BACE1 inhibitor clinical development concern the level of BACE1 inhibition and the stage of $\mathrm{AD}$ at which to treat for optimal efficacy. Hypothetical arguments based on the A673T APP mutation and BACE1+/- mice suggest that 50\% BACE1 inhibition might achieve $\sim 20 \% A \beta$ reduction, which could prevent $\mathrm{AD}$ if begun well before significant amyloid deposition. However, it is unclear whether any level of BACE1 inhibition can be effective if major amyloid accumulation is present in the brain. Amyloid PET imaging, CSF A 342 measurement, and other biomarker studies suggest that amyloid deposition starts years, even decades, before the clinical diagnosis of dementia. Moreover, the relationships between amyloid burden and cognitive impairment are not sufficiently well understood to determine the stage of $\mathrm{AD}$ that BACE1 inhibitor treatment would be most effective. Results from ongoing biomarker studies, future treatment and prevention trial, and pharmacodynamic modeling are expected to establish the appropriate level of BACE1 inhibition and stage of $\mathrm{AD}$ for optimal efficacy. Like the statins for hypercholesterolemia, the hope is that a therapeutic window of BACE1 inhibitor doses might be found that reduces cerebral $A \beta$ levels enough for efficacy, yet maintains sufficient BACE1 activity for the avoidance of side effects.
When eventually published, the results of the current BACE1 inhibitor clinical trials will prove invaluable for solving these important questions. We are at a crucial juncture in BACE1 inhibitor drug development, and the therapeutic potential of BACE1 inhibition for AD will be definitively answered in the not too distant future.

\section{Abbreviations}

AD: Alzheimer's disease; APP: Amyloid precursor protein; A $\beta$ : $\beta$-amyloid peptide; BACE1: $\beta$-site APP cleaving enzyme 1; C99: Carboxy-terminal 99 amino acid fragment of APP generated by BACE1 cleavage; SAPP $\beta$ : Amino terminal ectodomain fragment of APP generated by BACE1 cleavage.

\section{Competing interests}

R.V. has consulted for Eisai, Lilly, and Vitae Pharmaceutical Co.; his research funding sources include NIH R01AG022560, R01AG030142, Cure Alzheimer's Fund, Baila Foundation, BrightFocus Foundation, and the Alzheimer's Association.

\section{Authors' contributions}

RV planned the review, searched the primary sources of information, and wrote the review.

\section{Authors' information}

RV is Professor of Cell and Molecular Biology at the Feinberg School of Medicine, Northwstern University, Chicago, IL, USA. He co-discovered BACE1 in 1999 and currently conducts research on the physiological functions of BACE1 and the role of BACE1 in Alzheimer's disease.

\section{Acknowledgements}

I thank Dr. Patty Kandalepas for making the figures. I also thank Drs. Bruce Albala and Patrick May for reading and making useful comments on the Eisai and Lilly BACE1 inhibitor clinical trial sections, respectively.

Published online: 24 December 2014

\section{References}

1. Hardy J, Selkoe DJ: The amyloid hypothesis of Alzheimer's disease: progress and problems on the road to therapeutics. Science 2002, 297:353-356.

2. Tanzi RE: The genetics of Alzheimer disease. Cold Spring Harb Perspect Med 2012, 2.

3. Rutten BP, Steinbusch HW: Current concepts in Alzheimer's Disease: molecules, models and translational perspectives. Mol Neurodegener 2013, 8:33.

4. Vassar R, Kovacs DM, Yan R, Wong PC: The beta-secretase enzyme BACE in health and Alzheimer's disease: regulation, cell biology, function, and therapeutic potential. J Neurosci 2009, 29:12787-12794.

5. Sisodia SS, St George-Hyslop PH: gamma-Secretase, Notch, Abeta and Alzheimer's disease: where do the presenilins fit in? Nat Rev Neurosci 2002, 3:281-290.

6. De Strooper B, Vassar R, Golde T: The secretases: enzymes with therapeutic potential in Alzheimer disease. Nat Rev Neurol 2010, 6:99-107.

7. Walter J, van Echten-Deckert G: Cross-talk of membrane lipids and Alzheimer-related proteins. Mol Neurodegener 2013, 8:34.

8. Mullan M, Crawford F, Houlden H, Axelman K, Lilius L, Winblad B, Lannfelt L: A pathogenic mutation for probable Alzheimer's disease in the APP gene at the N-terminus of beta-amyloid. Nat Genet 1992, 1:345-347.

9. Di Fede G, Catania M, Morbin M, Rossi G, Suardi S, Mazzoleni G, Merlin M, Giovagnoli AR, Prioni S, Erbetta A, Falcone C, Gobbi M, Colombo L, Bastone A, Beeg M, Manzoni C, Francescucci B, Spagnoli A, Cantu L, Del Favero E, Levy E, Salmona M, Tagliavini F: A recessive mutation in the APP gene with dominant-negative effect on amyloidogenesis. Science 2009, 323:1473-1477.

10. Jonsson T, Atwal JK, Steinberg S, Snaedal J, Jonsson PV, Bjornsson S, Stefansson H, Sulem P, Gudbjartsson D, Maloney J, Hoyte K, Gustafson A, Liu Y, Lu Y, Bhangale T, Graham RR, Huttenlocher J, Bjornsdottir G, Andreassen OA, Jonsson EG, Palotie A, Behrens TW, Magnusson OT, Kong A, Thorsteinsdottir U, Watts RJ, Stefansson K: A mutation in APP protects against Alzheimer's disease and age-related cognitive decline. Nature 2012, 488:96-99. 
11. Maloney JA, Bainbridge T, Gustafson A, Zhang S, Kyauk R, Steiner P, van der Brug M, Liu Y, Ernst JA, Watts RJ, Atwal JK: Molecular mechanisms of Alzheimer disease protection by the A673T Allele of amyloid precursor protein. J Biol Chem 2014, 289:30990-31000

12. Benilova I, Gallardo R, Ungureanu AA, Castillo Cano V, Snellinx A, Ramakers M, Bartic C, Rousseau F, Schymkowitz J, De Strooper B: The Alzheimer disease protective mutation A2T modulates kinetic and thermodynamic properties of Amyloid-beta (Abeta) aggregation. J Bio/ Chem 2014, 289:30977-30989.

13. Vassar R, Bennett BD, Babu-Khan S, Kahn S, Mendiaz EA, Denis P, Teplow DB, Ross S, Amarante P, Loeloff R, Luo Y, Fisher S, Fuller J, Edenson S, Lile J, Jarosinski MA, Biere AL, Curran E, Burgess T, Louis JC, Collins F, Treanor J, Rogers G, Citron M: Beta-secretase cleavage of Alzheimer's amyloid precursor protein by the transmembrane aspartic protease BACE. Science 1999, 286:735-741.

14. Yan R, Bienkowski MJ, Shuck ME, Miao H, Tory MC, Pauley AM, Brashier JR, Stratman NC, Mathews WR, Buhl AE, Carter DB, Tomasselli AG, Parodi LA, Heinrikson RL, Gurney ME: Membrane-anchored aspartyl protease with Alzheimer's disease beta-secretase activity. Nature 1999, 402:533-537.

15. Sinha S, Anderson JP, Barbour R, Basi GS, Caccavello R, Davis D, Doan M, Dovey HF, Frigon N, Hong J, Jacobson-Croak K, Jewett N, Keim P, Knops J, Lieberburg I, Power M, Tan H, Tatsuno G, Tung J, Schenk D, Seubert P, Suomensaari SM, Wang S, Walker D, Zhao J, McConlogue L, John V: Purification and cloning of amyloid precursor protein beta-secretase from human brain. Nature 1999, 402:537-540.

16. Hussain I, Powell D, Howlett DR, Tew DG, Meek TD, Chapman C, Gloger IS, Murphy KE, Southan CD, Ryan DM, Smith TS, Simmons DL, Walsh FS, Dingwall C, Christie G: Identification of a novel aspartic protease (Asp 2) as beta-secretase. Mol Cell Neurosci 1999, 14:419-427.

17. Lin X, Koelsch G, Wu S, Downs D, Dashti A, Tang J: Human aspartic protease memapsin 2 cleaves the beta-secretase site of beta-amyloid precursor protein. Proc Natl Acad Sci U S A 2000, 97:1456-1460.

18. Solans A, Estivill X, de La Luna S: A new aspartyl protease on 21q22.3, BACE2, is highly similar to Alzheimer's amyloid precursor protein betasecretase. Cytogenet Cell Genet 2000, 89:177-184.

19. Bennett BD, Babu-Khan S, Loeloff R, Louis JC, Curran E, Citron M, Vassar R: Expression analysis of BACE2 in brain and peripheral tissues. J Biol Chem 2000, 275:20647-20651.

20. Laird FM, Cai H, Savonenko AV, Farah MH, He K, Melnikova T, Wen $H$ Chiang HC, Xu G, Koliatsos VE, Borchelt DR, Price DL, Lee HK, Wong PC: BACE1, a major determinant of selective vulnerability of the brain to amyloid-beta amyloidogenesis, is essential for cognitive, emotional, and synaptic functions. J Neurosci 2005, 25:11693-11709.

21. Farzan M, Schnitzler CE, Vasilieva N, Leung D, Choe H: BACE2, a b-secretase homolog, cleaves at the $b$ site and within the amyloid-b region of the amyloid-b precursor protein. Proc Natl Acad Sci U S A 2000, 97:9712-9717.

22. Yan R, Munzner JB, Shuck ME, Bienkowski MJ: BACE2 functions as an alternative alpha-secretase in cells. J Biol Chem 2001, 276:34019-34027.

23. Fluhrer R, Capell A, Westmeyer G, Willem M, Hartung B, Condron MM, Teplow DB, Haass C, Walter J: A non-amyloidogenic function of BACE-2 in the secretory pathway. J Neurochem 2002, 81:1011-1020.

24. Basi G, Frigon N, Barbour R, Doan T, Gordon G, McConlogue L, Sinha S, Zeller M: Antagonistic effects of beta-site amyloid precursor proteincleaving enzymes 1 and 2 on beta-amyloid peptide production in cells. J Biol Chem 2003, 278:31512-31520.

25. Abdul-Hay SO, Sahara T, McBride M, Kang D, Leissring MA: Identification of BACE2 as an avid ss-amyloid-degrading protease. Mol Neurodegener 2012, 7:46.

26. Luo Y, Bolon B, Kahn S, Bennett BD, Babu-Khan S, Denis P, Fan W, Kha H, Zhang J, Gong Y, Martin L, Louis JC, Yan Q, Richards WG, Citron M, Vassar R: Mice deficient in BACE1, the Alzheimer's beta-secretase, have normal phenotype and abolished beta-amyloid generation. Nat Neurosci 2001, 4:231-232.

27. Roberds SL, Anderson J, Basi G, Bienkowski MJ, Branstetter DG, Chen KS, Freedman SB, Frigon NL, Games D, Hu K, Johnson-Wood K, Kappenman KE, Kawabe TT, Kola I, Kuehn R, Lee M, Liu W, Motter R, Nichols NF, Power M, Robertson DW, Schenk D, Schoor M, Shopp GM, Shuck ME, Sinha S, Svensson KA, Tatsuno G, Tintrup H, Wijsman J, et al: BACE knockout mice are healthy despite lacking the primary beta-secretase activity in brain: implications for Alzheimer's disease therapeutics. Hum Mol Genet 2001 10:1317-1324

28. Cai H, Wang Y, McCarthy D, Wen H, Borchelt DR, Price DL, Wong PC: BACE1 is the major beta-secretase for generation of Abeta peptides by neurons. Nat Neurosci 2001, 4:233-234.
29. Dominguez D, Tournoy J, Hartmann D, Huth T, Cryns K, Deforce S, Serneels L, Camacho IE, Marjaux E, Craessaerts K, Roebroek AJ, Schwake M, D'Hooge R, Bach P, Kalinke U, Moechars D, Alzheimer C, Reiss K, Saftig P, De Strooper B: Phenotypic and biochemical analyses of BACE1- and BACE2-deficient mice. J Biol Chem 2005, 280:30797-30806.

30. Ohno M, Sametsky EA, Younkin LH, Oakley H, Younkin SG, Citron M, Vassar R, Disterhoft JF: BACE1 deficiency rescues memory deficits and cholinergic dysfunction in a mouse model of Alzheimer's disease. Neuron 2004, 41:27-33.

31. Luo Y, Bolon B, Damore MA, Fitzpatrick D, Liu H, Zhang J, Yan Q, Vassar R, Citron M: BACE1 (beta-secretase) knockout mice do not acquire compensatory gene expression changes or develop neural lesions over time. Neurobiol Dis 2003, 14:81-88.

32. Ohno M, Cole SL, Yasvoina M, Zhao J, Citron M, Berry R, Disterhoft JF, Vassar R: BACE1 gene deletion prevents neuron loss and memory deficits in 5XFAD APP/PS1 transgenic mice. Neurobiol Dis 2007, 26:134-145.

33. McConlogue L, Buttini M, Anderson JP, Brigham EF, Chen KS, Freedman SB, Games D, Johnson-Wood K, Lee M, Zeller M, Liu W, Motter R, Sinha S: Partial reduction of BACE1 has dramatic effects on Alzheimer plaque and synaptic pathology in APP Transgenic Mice. J Biol Chem 2007, 282:26326-26334.

34. Kandalepas PC, Sadleir KR, Eimer WA, Zhao J, Nicholson DA, Vassar R: The Alzheimer's beta-secretase BACE1 localizes to normal presynaptic terminals and to dystrophic presynaptic terminals surrounding amyloid plaques. Acta Neuropathol 2013, 126:329-352

35. Deng M, He W, Tan Y, Han H, Hu X, Xia K, Zhang Z, Yan R: Increased expression of reticulon 3 in neurons leads to reduced axonal transport of beta site amyloid precursor protein-cleaving enzyme 1. J Biol Chem 2013, 288:30236-30245.

36. Rajapaksha TW, Eimer WA, Bozza TC, Vassar R: The Alzheimer's beta-secretase enzyme BACE1 is required for accurate axon guidance of olfactory sensory neurons and normal glomerulus formation in the olfactory bulb. Mol Neurodegener 2011, 6:88.

37. Cao L, Rickenbacher GT, Rodriguez S, Moulia TW, Albers MW: The precision of axon targeting of mouse olfactory sensory neurons requires the BACE1 protease. Sci Rep 2012, 2:231.

38. Hitt B, Riordan S, Kukreja L, Eimer W, Rajapaksha T, Vassar R: Beta-site amyloid precursor protein (APP) cleaving enzyme 1 (BACE1) deficient mice exhibit a close homolog of L1 (CHL1) loss-of-function phenotype involving axon guidance defects. J Biol Chem 2012, 287:38408-38425.

39. Willem M, Garratt AN, Novak B, Citron M, Kaufmann S, Rittger A, DeStrooper B, Saftig P, Birchmeier C, Haass C: Control of peripheral nerve myelination by the beta-secretase BACE1. Science 2006, 314:664-666.

40. Hu X, Hicks CW, He W, Wong P, Macklin WB, Trapp BD, Yan R: Bace1 modulates myelination in the central and peripheral nervous system. Nat Neurosci 2006, 9:1520-1525.

41. Hu X, He W, Diaconu C, Tang X, Kidd GJ, Macklin WB, Trapp BD, Yan R: Genetic deletion of BACE1 in mice affects remyelination of sciatic nerves. FASEB J 2008, 22:2970-2980.

42. Kobayashi D, Zeller M, Cole T, Buttini M, McConlogue L, Sinha S, Freedman S, Morris RG, Chen KS: BACE1 gene deletion: impact on behavioral function in a model of Alzheimer's disease. Neurobiol Aging 2008, 29:861-873.

43. Ohno M, Chang L, Tseng W, Oakley H, Citron M, Klein WL, Vassar R, Disterhoft JF: Temporal memory deficits in Alzheimer's mouse models: rescue by genetic deletion of BACE1. Eur J Neurosci 2006, 23:251-260.

44. Cheret C, Willem M, Fricker FR, Wende H, Wulf-Goldenberg A, Tahirovic S, Nave KA, Saftig P, Haass C, Garratt AN, Bennett DL, Birchmeier C: Bace1 and Neuregulin-1 cooperate to control formation and maintenance of muscle spindles. EMBO J 2013, 32:2015-2028.

45. Harrison SM, Harper AJ, Hawkins J, Duddy G, Grau E, Pugh PL, Winter PH, Shilliam CS, Hughes ZA, Dawson LA, Gonzalez MI, Upton N, Pangalos MN, Dingwall C: BACE1 (beta-secretase) transgenic and knockout mice: identification of neurochemical deficits and behavioral changes. Mol Cell Neurosci 2003, 24:646-655.

46. Hu X, He W, Luo X, Tsubota KE, Yan R: BACE1 Regulates Hippocampal Astrogenesis via the Jagged1-Notch Pathway. Cell Rep 2013, 4:40-49.

47. Hu X, Zhou X, He W, Yang J, Xiong W, Wong P, Wilson CG, Yan R: BACE1 deficiency causes altered neuronal activity and neurodegeneration. J Neurosci 2010, 30:8819-8829.

48. Savonenko AV, Melnikova T, Laird FM, Stewart KA, Price DL, Wong PC: Alteration of BACE1-dependent NRG1/ErbB4 signaling and schizophrenia-like phenotypes in BACE1-null mice. Proc Natl Acad Sci U S A 2008, 105:5585-5590. 
49. Cai J, Qi X, Kociok N, Skosyrski S, Emilio A, Ruan Q, Han S, Liu L, Chen Z, Bowes Rickman C, Golde T, Grant MB, Saftig P, Serneels L, de Strooper B, Joussen AM, Boulton ME: beta-Secretase (BACE1) inhibition causes retinal pathology by vascular dysregulation and accumulation of age pigment. EMBO Mol Med 2012, 4:980-991.

50. Hitt BD, Jaramillo TC, Chetkovich DM, Vassar R: BACE1-/- mice exhibit seizure activity that does not correlate with sodium channel level or axonal localization. Mol Neurodegener 2010, 5:31.

51. Meakin PJ, Harper AJ, Hamilton DL, Gallagher J, McNeilly AD, Burgess LA, Vaanholt LM, Bannon KA, Latcham J, Hussain I, Speakman JR, Howlett DR, Ashford ML: Reduction in BACE1 decreases body weight, protects against diet-induced obesity and enhances insulin sensitivity in mice. Biochem J 2012, 441:285-296.

52. Hoffmeister A, Tuennemann J, Sommerer I, Mossner J, Rittger A, Schleinitz D, Kratzsch J, Rosendahl J, Kloting N, Stahl T, Rossner S, Paroni F, Maedler K, Kovacs $P$, Blüher M: Genetic and biochemical evidence for a functional role of BACE1 in the regulation of insulin mRNA expression. Obesity (Silver Spring) 2013, 21:E626-E633.

53. Kim DY, Carey BW, Wang H, Ingano LA, Binshtok AM, Wertz MH, Pettingell WH, He P, Lee VM, Woolf CJ, Kovacs DM: BACE1 regulates voltage-gated sodium channels and neuronal activity. Nat Cell Biol 2007, 9:755-764.

54. Esterhazy D, Stutzer I, Wang $H$, Rechsteiner MP, Beauchamp J, Dobeli $H_{\text {, }}$ Hilpert H, Matile H, Prummer M, Schmidt A, Lieske N, Boehm B, Marselli L, Bosco D, Kerr-Conte J, Aebersold R, Spinas GA, Moch H, Migliorini C, Stoffel M: Bace2 is a beta cell-enriched protease that regulates pancreatic beta cell function and mass. Cell Metab 2011, 14:365-377.

55. Rochin L, Hurbain I, Serneels L, Fort C, Watt B, Leblanc P, Marks MS, De Strooper B, Raposo G, van Niel G: BACE2 processes PMEL to form the melanosome amyloid matrix in pigment cells. Proc Natl Acad Sci U S A 2013, 110:10658-10663.

56. Kuhn PH, Koroniak K, Hogl S, Colombo A, Zeitschel U, Willem M, Volbracht C, Schepers U, Imhof A, Hoffmeister A, Haass C, Rossner S, Brase S, Lichtenthaler SF: Secretome protein enrichment identifies physiological BACE1 protease substrates in neurons. EMBO J 2012, 31:3157-3168.

57. Zhou L, Barao S, Laga M, Bockstael K, Borgers M, Gijsen H, Annaert W, Moechars D, Mercken M, Gevaer K, De Strooper B: The neural cell adhesion molecules $\mathrm{L} 1$ and $\mathrm{CHL} 1$ are cleaved by BACE1 protease in vivo. $J$ Biol Chem 2012, 287:25927-25940.

58. Fleck D, van Bebber F, Colombo A, Galante C, Schwenk BM, Rabe L, Hampel H, Novak B, Kremmer E, Tahirovic S, Edbauer D, Lichtenthaler SF, Schmid B, Willem M, Haass C: Dual cleavage of neuregulin 1 type III by BACE1 and ADAM17 liberates its EGF-like domain and allows paracrine signaling. J Neurosci 2013, 33:7856-7869.

59. Luo X, Prior M, He W, Hu X, Tang X, Shen W, Yadav S, Kiryu-Seo S, Miller R, Trapp BD, Yan R: Cleavage of neuregulin-1 by BACE1 or ADAM10 protein produces differential effects on myelination. J Biol Chem 2011, 286:23967-23974.

60. Heyden A, Angenstein F, Sallaz M, Seidenbecher C, Montag D: Abnormal axonal guidance and brain anatomy in mouse mutants for the cell recognition molecules close homolog of $\mathrm{L} 1$ and $\mathrm{NgCAM}$-related cell adhesion molecule. Neuroscience 2008, 155:221-233.

61. Montag-Sallaz M, Schachner M, Montag D: Misguided axonal projections, neural cell adhesion molecule 180 mRNA upregulation, and altered behavior in mice deficient for the close homolog of L1. Mol Cell Biol 2002, 22:7967-7981

62. Kopan R, llagan MX: The canonical Notch signaling pathway: unfolding the activation mechanism. Cell 2009, 137:216-233.

63. Hong L, Turner RT 3rd, Koelsch G, Shin D, Ghosh AK, Tang J: Crystal structure of memapsin 2 (beta-secretase) in complex with an inhibitor OM00-3. Biochemistry 2002, 41:10963-10967.

64. Hong L, Koelsch G, Lin X, Wu S, Terzyan S, Ghosh AK, Zhang XC, Tang J: Structure of the protease domain of memapsin 2 (beta-secretase) complexed with inhibitor. Science 2000, 290:150-153.

65. Probst G, Xu YZ: Small-molecule BACE1 inhibitors: a patent literature review (2006-2011). Expert Opin Ther Pat 2012, 22:511-540.

66. Evin $G$, Lessene $G$, Wilkins S: BACE inhibitors as potential drugs for the treatment of Alzheimer's disease: focus on bioactivity. Recent Pat CNS Drug Discov 2011, 6:91-106.

67. Marques F, Sousa JC, Sousa N, Palha JA: Blood-brain-barriers in aging and in Alzheimer's disease. Mol Neurodegener 2013, 8:38.
68. May PC, Dean RA, Lowe SL, Martenyi F, Sheehan SM, Boggs LN, Monk SA, Mathes BM, Mergott DJ, Watson BM, Stout SL, Timm DE, Smith Labell E, Gonzales CR, Nakano M, Jhee SS, Yen M, Ereshefsky L, Lindstrom TD, Calligaro DO, Cocke PJ, Greg Hall D, Friedrich S, Citron M, Audia JE: Robust central reduction of amyloid-beta in humans with an orally available, non-peptidic beta-secretase inhibitor. J Neurosci 2011, 31:16507-16516.

69. Martenyi F, Dean RA, Lowe S, Nakano M, Monk S, Willis BA, Gonzales C, Mergott D, Leslie D, May P, James A, Gevorkyan H, Jhee S, Ereshefsky L, Citron M: BACE inhibitor LY2886721 safety and central and peripheral PK and PD in healthy subjects (HSs). Alzheimers Dement 2012, 8:P583-P584.

70. Willis B, Martenyi F, Dean R, Lowe S, Nakano M, Monk S, Gonzales C, Mergott D, Daugherty L, Citron M, May P: Central BACE1 inhibition by LY2886721 produces opposing effects on APP processing as reflected by cerebrospinal fluid sAPPalpha and sAPPbeta. Alzheimers Dement 2012, 8:P582.

71. May PC, Mergott DJ, Cocke PJ, Monk SA, Boggs LN, Sanchez-Felix MV, Audia JE, Calligaro DO, Citron M, Dean RA, Lowe SL, Daugherty LL, Gonzales CR, Nakano $M$, Willis BA, Martenyi F: Preclinical and Phase I clinical characterization of LY2886721, a BACE inhibitor in Phase II development Alzheimer's disease. The 11th International Conference On Alzheimer's \& Parkinson's Diseases, Florence, Italy, March 6-10, 2013.

72. Forman M, Palcza J, Tseng J, Leempoels J, Ramael S, Han D, Jhee S, Ereshefsky L, Tanen M, Laterza O, Dockendorf M, Krishna G, Ma L, Wagner J, Troyer M: The novel BACE inhibitor MK-8931 dramatically lowers cerebrospinal fluid $A \beta$ peptides in health subjects following single- and multiple-dose administration. Alzheimers Dement 2012, 8:P704.

73. Forman M, Kleijn H, Dockendorf M, Palcza J, Tseng J, Canales C, Egan M, Kennedy M, Laterza O, Ma L, Scott J, Tanen M, Apter J, Backonja M, Ereshefsky L, Gevorkyan H, Jhee S, Rynders R, Zari A, Bryan E, Wagner J, Troyer M, Stone J: The novel BACE inhibitor MK-8931 dramatically lowers CSF beta-amyloid in patients with mild-to-moderate Alzheimer's disease. Alzheimers Dement 2013, 9:P139.

74. Alexander R, Budd S, Russell M, Kugler A, Cebers G, Ye N, Olsson T, Burdette D, Maltby J, Paraskos J, Elsby K, Han D, Goldwater R, Ereshefsky L: AZD3293 a novel bace1 inhibitor: safety, tolerability and effects on plasma and CSF Ab peptides following single- and multiple-dose administration. Neurobiol Aging 2014, 35:S2.

75. Höglund $K$, Salter $H$, Zetterberg $H$, Andreason U, Olsson T, Alexander R, Kugler A, Cebers G, Ye N, Burdette D, Budd Haeberlein SL: Monitoring the Soluble Amyloid Precursor Protein Alpha (SAPPA) and Beta (SAPPB) fragments in plasma and CSF from healthy individuals treated with bace inhibitor AZD3293 in a multiple ascending dose study: Pharmacokinetic and Pharmacodynamic correlate. Alzheimers Dement 2014, 10:P447.

76. Lai R, Albala B, Kaplow JM, Aluri J, Yen M, Satlin A: First-in-human study of E2609, a novel BACE1 inhibitor, demonstrates prolonged reductions in plasma beta-amyloid levels after single dosing. Alzheimers Dement 2012, 8:P96.

77. Lai R, Albala B, Kaplow JM, Majid O, Matijevic M, Aluri J, Satlin A: Novel BACE1 inhibitor E2609 reduces plasma and CSF amyloid in health subjects after 14 days oral administration. The 11th International Conference On Alzheimer's \& Parkinson's Diseases, Florence, Italy, March 6-10, 2013.

78. Bernier F, Sato Y, Matijevic M, Desmond H, McGrath S, Burns L, Kaplow JM, Albala B: Clinical study of E2609, a novel BACE1 inhibitor, demonstrates target engagement and inhibition of BACE1 activity in CSF. Alzheimers Dement 2013, 9:P886.

79. Chami L, Checler F: BACE1 is at the crossroad of a toxic vicious cycle involving cellular stress and beta-amyloid production in Alzheimer's disease. Mol Neurodegener 2012, 7:52.

80. Zhao Y, Wang Y, Yang J, Wang X, Zhao Y, Zhang X, Zhang YW: Sorting nexin 12 interacts with BACE1 and regulates BACE1-mediated APP processing. Mol Neurodegener 2012, 7:30.

81. Rossner S, Sastre M, Bourne K, Lichtenthaler SF: Transcriptional and translational regulation of BACE1 expression-implications for Alzheimer's disease. Prog Neurobiol 2006, 79:95-111.

82. Sun X, He G, Qing H, Zhou W, Dobie F, Cai F, Staufenbiel M, Huang LE, Song W: Hypoxia facilitates Alzheimer's disease pathogenesis by up-regulating BACE1 gene expression. Proc Natl Acad Sci U S A 2006, 103:18727-18732.

83. Zhang X, Zhou K, Wang R, Cui J, Lipton SA, Liao FF, Xu H, Zhang MW: Hypoxiainducible factor 1alpha (HIF-1alpha)-mediated hypoxia increases BACE1 expression and beta-amyloid generation. J Biol Chem 2007, 282:10873-10880.

84. Sadleir KR, Eimer WA, Kaufman RJ, Osten P, Vassar R: Genetic inhibition of phosphorylation of the translation initiation factor elF2a does not block $A \beta$-dependent elevation of BACE1 and APP levels or reduce amyloid pathology in a mouse model of Alzheimer's disease. PLOS One 2014, 9 
85. Sadleir KR, Vassar R: Cdk5 protein inhibition and Abeta42 increase BACE1 protein level in primary neurons by a post-transcriptional mechanism: implications of CDK5 as a therapeutic target for Alzheimer disease. J Biol Chem 2012, 287:7224-7235.

86. Arbel M, Yacoby I, Solomon B: Inhibition of amyloid precursor protein processing by beta-secretase through site-directed antibodies. Proc Natl Acad Sci U S A 2005, 102:7718-7723.

87. Boddapati S, Levites $Y$, Sierks MR: Inhibiting beta-secretase activity in Alzheimer's disease cell models with single-chain antibodies specifically targeting APP. J Mol Biol 2011, 405:436-447.

88. Rabinovich-Nikitin I, Rakover IS, Becker M, Solomon B: Beneficial effect of antibodies against beta- secretase cleavage site of APP on Alzheimer'slike pathology in triple-transgenic mice. PLoS One 2012, 7:e46650.

89. Atwal JK, Chen Y, Chiu C, Mortensen DL, Meilandt WJ, Liu Y, Heise CE, Hoyte K, Luk W, Lu Y, Peng K, Wu P, Rouge L, Zhang Y, Lazarus RA, Scearce-Levie K, Wang W, Wu Y, Tessier-Lavigne M, Watts RJ: A therapeutic antibody targeting BACE1 inhibits amyloid-beta production in vivo. Sci Trans/ Med 2011, 3:84ra43.

90. Zhou L, Chavez-Gutierrez L, Bockstael K, Sannerud R, Annaert W, May PC, Karran E, De Strooper B: Inhibition of beta-secretase in vivo via antibody binding to unique loops (D and F) of BACE1. J Biol Chem 2011, 286:8677-8687.

91. Wang W, Liu Y, Lazarus RA: Allosteric inhibition of BACE1 by an exositebinding antibody. Curr Opin Struct Biol 2013, 23:797-805.

92. Yu YJ, Zhang Y, Kenrick M, Hoyte K, Luk W, Lu Y, Atwal J, Elliott JM, Prabhu S, Watts RJ, Dennis MS: Boosting brain uptake of a therapeutic antibody by reducing its affinity for a transcytosis target. Sci Transl Med 2011, 3:84ra44.

93. Yu YJ, Atwal JK, Zhang Y, Tong RK, Wildsmith KR, Tan C, Bien-Ly N, Hersom M, Maloney JA, Meilandt WJ, Bumbaca D, Gadkar K, Hoyte K, Luk W, Lu Y, Ernst JA, Scearce-Levie K, Couch JA, Dennis MS, Watts RJ: Therapeutic bispecific antibodies cross the blood-brain barrier in nonhuman primates. Sci Transl Med 2014, 6:261ra154.

94. Li R, Lindholm K, Yang LB, Yue X, Citron M, Yan R, Beach T, Sue L, Sabbagh M, Cai $H$, Wong $P$, Price $D$, Shen $Y$ : Amyloid beta peptide load is correlated with increased beta-secretase activity in sporadic Alzheimer's disease patients. Proc Natl Acad Sci U S A 2004, 101:3632-3637.

95. Yang LB, Lindholm K, Yan R, Citron M, Xia W, Yang XL, Beach T, Sue L, Wong P, Price D, Li R, Shen Y: Elevated beta-secretase expression and enzymatic activity detected in sporadic Alzheimer disease. Nat Med 2003, 9:3-4

96. Fukumoto $\mathrm{H}$, Cheung BS, Hyman BT, Irizarry MC: Beta-secretase protein and activity are increased in the neocortex in Alzheimer disease. Arch Neurol 2002, 59:1381-1389.

97. Holsinger RM, McLean CA, Beyreuther K, Masters CL, Evin G: Increased expression of the amyloid precursor beta-secretase in Alzheimer's disease. Ann Neurol 2002, 51:783-786.

98. Zhao J, Fu Y, Yasvoina M, Shao P, Hitt B, O'Connor T, Logan S, Maus E, Citron M, Berry R, Binder L, Vassar R: Beta-site amyloid precursor protein cleaving enzyme 1 levels become elevated in neurons around amyloid plaques: implications for Alzheimer's disease pathogenesis. J Neurosci 2007 27:3639-3649.

99. Zhang XM, Cai Y, Xiong K, Cai H, Luo XG, Feng JC, Clough RW, Struble RG, Patrylo PR, Yan XX: Beta-secretase-1 elevation in transgenic mouse models of Alzheimer's disease is associated with synaptic/axonal pathology and amyloidogenesis: implications for neuritic plaque development. Eur J Neurosci 2009, 30:2271-2283

100. Torres M, Jimenez S, Sanchez-Varo R, Navarro V, Trujillo-Estrada L, SanchezMejias E, Carmona I, Davila JC, Vizuete M, Gutierrez A, Vitorica J: Defective lysosomal proteolysis and axonal transport are early pathogenic events that worsen with age leading to increased APP metabolism and synaptic Abeta in transgenic APP/PS1 hippocampus. Mol Neurodegener 2012, 7:59.

101. Jack CR Jr: Alzheimer disease: new concepts on its neurobiology and the clinical role imaging will play. Radiology 2012, 263:344-361.

102. Holtzman DM, Morris JC, Goate AM: Alzheimer's disease: the challenge of the second century. Sci Transl Med 2011, 3:77sr71.

103. Musiek ES, Holtzman DM: Origins of Alzheimer's disease: reconciling cerebrospinal fluid biomarker and neuropathology data regarding the temporal sequence of amyloid-beta and tau involvement. Curr Opin Neurol 2012, 25:715-720.

104. Tarawneh R, Holtzman DM: The clinical problem of symptomatic Alzheimer disease and mild cognitive impairment. Cold Spring Harb Perspect Med 2012, 2:a006148.
105. Jack CR Jr, Holtzman DM: Biomarker modeling of Alzheimer's disease. Neuron 2013, 80:1347-1358.

106. Rosen C, Hansson O, Blennow K, Zetterberg H: Fluid biomarkers in Alzheimer's disease - current concepts. Mol Neurodegener 2013, 8:20.

107. Lemere CA: Immunotherapy for Alzheimer's disease: hoops and hurdles. Mol Neurodegener 2013, 8:36.

108. Salzer JL: Axonal regulation of Schwann cell ensheathment and myelination. J Peripher Nerv Syst 2012, 17:14-19. 